\title{
The genus Microdonophagus Schauff (Hymenoptera: Eulophidae), with description of a new species
}

\author{
CHRISTER HANSSON \\ Department of COB, Zoology, Lund University, Helgonavägen 3, SE-22362 Lund, Sweden. E-mail: Christer.Hansson@cob.lu.se
}

\begin{abstract}
A second species of the hitherto monotypic genus Microdonophagus Schauff is described as Microdonophagus levis sp. nov. The species is described from material collected at La Selva Biological Research Station in Costa Rica. Unlike the previously described species, Microdonophagus woodleyi Schauff, it is described from females only and the biology is not known. The addition of a second species of Microdonophagus enhances the possibilities to assess the characters defining the genus, some of which are introduced as new here.
\end{abstract}

Key words: Chalcidoidea, Entedoninae, neotropical, La Selva, Costa Rica, taxonomy

\section{Introduction}

The type species of the genus Microdonophagus, M. woodleyi Schauff, is odd, in both its highly dimorphic male and its biology. The genus and species were both described by Schauff (1986) and until now Microdonophagus has contained only a single species. Hansson (2002) updated the distributional data of $M$. woodleyi, from Panama to Colombia, but no additional species had been found at that time.

The male of Microdonophagus woodleyi has a very peculiar appearance (see fig. 1 in Schauff, 1986). The small eyes, strongly swollen femora, and the reduced wings are unique features within the subfamily Entedoninae. Males of some species of Melittobia and Tachinobia repanda Bouček also have these characters but belong in Tetrastichinae (Eulophidae). Many males of fig-wasps (Agaonidae) have adaptations similar to those of males of $M$. woodleyi (e.g. Bouček 1988), including small eyes (missing in some species), short wings (missing in some species) and swollen femora. The scattered occurrence of these adaptations represents convergent evolution. The female also has several unique and presumably derived characters (see below), some of which are introduced as new here.

This is a remarkable genus also from a biological view. The specimens in the type series of $M$. woodleyi were reared from larvae of Microdon sp. (Diptera: Syrphidae) living in nests of the ant Tapinoma fulvum Wheeler (Hymenoptera: Formicidae) (Schauff 1986). The 41 females and five males in the type series of $M$. woodleyi were evidently reared from more than one host larva but no specific account of the number of wasps that emerged from each host-larva was given. However, in the description of $M$. woodleyi, Schauff stated that he had seen a single Microdon larva in alcohol with 60-70 specimens of Microdonophagus pupae on the inside of the larva. Clearly, as stated by Schauff, $M$. woodleyi is a gregarious parasitoid.

A second species of Microdonophagus from Costa Rica is described here. The inclusion of a second species improves the possibilities to assess the characters defining the genus. The description of the new species is based on females only. No males have been found, but if the biology of this second species is similar to M. woodleyi then males probably will be found only in ant nests. The description is based on females which were swept at La Selva Biological Research Station, a locality situated in premontane rainforest in Costa Rica. 